\title{
Inclusive Growth: Comprehensive Dimension of Income Distribution
}

The article aims to solve the problem of unequal income distribution in Malaysia. Income inequality did not change significantly since 1990. Inclusive growth is an alternative way that can help the government overcome the unequal distribution of income. However, there are no measurements or detailed studies conducted in Malaysia. Moreover, the country's distribution policy for the 2016-2030 period focuses on inclusive economic growth. Based on the above gaps, we constructed the Malaysia Inclusive Index and estimated the income distribution using this new composite index. To construct the index, we applied the Z-score method. We obtained data for this study from the World Development Indicator, Economic Planning Unit, Department of Statistics, Malaysia and annual reports from various ministries. The main research findings show yearon-year growth from 1990 to 2016, indicating that economic growth in Malaysia is increasingly inclusive. Therefore, to achieve inclusive and equitable economic growth in distribution, the government is advised to consider not only fiscal aspects, but also holistic components comprised of education, health, housing and employment of the B40 group (lower class). Simultaneously, the M40 group (middle class) should not be left out. Income distribution factors and the Malaysia Inclusive Index (MII) determinants such as investment, inflation, education and national income should be considered when developing national distribution policies, as these factors are crucial for inclusive growth in Malaysia.

Keywords: Inclusive Growth, Inequality, Household, Income Distribution, Expenditure

\section{Acknowledgments}

We would like to thank the Universiti Malaysia Terengganu, academic and non-academic staff and students for logistics and administrative support during the research work. We wish to express sincere appreciation to Ishak Yussof, Mohd Azlan Shah Zaidi and Noorasiah Sulaiman from Faculty of Economics and Management, National University of Malaysia for continuous support of young researchers. The article has been prepared with the financial support of the Universiti Malaysia Terengganu (vote 21000 for travel).

For citation: Che Sulaiman, N. F., Ab-Hamid, M. F. \& Ridzuan, A. R. (2021). Inclusive Growth: Comprehensive Dimension of Income Distribution. Ekonomika regiona [Economy of region], 17(1), 301-317, https://doi.org/10.17059/ekon. reg.2021-1-23

\footnotetext{
${ }^{1}$ (c) Che Sulaiman N. F., Ab-Hamid M. F., Ridzuan A. R. Text. 2021.
} 


\author{
Н. Ф. Че Сулейман ${ }^{\text {a) }}$, М. Ф. Аб-Хамид б), А. Р. Ридзуан ${ }^{\text {) }}$ \\ a) Университет Малайзии Теренггану, Теренггану, Малайзия \\ 6) Мультимедийный университет MMU, Сайберджая, Малайзия \\ в) Технологический университет MARA, Малакка, Малайзия \\ a) https://orcid.org/0000-0001-8323-6876,e-mail: n.fatimah@umt.edu.my
}

\title{
Инклюзивный рост: комплексный подход к распределению доходов
}

В статье рассматривается решение проблемь неравенства в распределении доходов в Малайзии. С 1990 г. доходы распределяются неравномерно. Выьор альтернативной стратегии инклюзивного роста может помочь в решении проблемь распределения доходов, однако в Малайзии исследований в этом направлении немного. В то же время, политика распределения доходов страны на период 2016-2030 г2. ориентирована на инклюзивный экономический рост. На основании вышеизложенного мы разработали комплексный показатель «малайзийский индекс включенности» и применили его для оценки распределения доходов. Для расчета данного показателя мы использовали методологию Z-оценок. Источниками данных для анализа стали материалы «Показателя мирового развития» (World Development Indicator), отдела экономического планирования департамента статистики Малайзии и годовых отчетов различных министерств. Результаты исследования показали ежегодньй рост показателей за период 1990-2016 г2., что говорит о том, что экономический рост в Малайзии становится становится все существеннее. Таким образом, для достижения инклюзивного экономического роста правительству необходимо не только рассматривать показатели доходов, населения, такие как образование, здравоохранение, жилье и занятость, для низшего класса (В40), но и принимать во внимание показатели среднего класса (М40). При разработке государственной политики распределения доходов необходимо учитьвать как факторь доходов, так и показатели Малайзийского индекса включенности (инвестиции, инфляция, образование, национальный доход), поскольку они значительно влияют на инклюзивный рост в Малайзии.

Ключевые слова: инклюзивный рост, неравенство, домохозяйство, распределение доходов, расходы

\section{Благодарность}

Авторы выражают благодарность Университету Малайзии Теренггану, преподавателям, сотрудникам и студентам за материально-техническое обеспечение во время исследовательской работы. Также авторы выражают искреннюю признательность Исхаку Юссофу, Мохд Азлану Шаху Заиди и Нурасайе Сулейману с факультета экономики и менеджмента Национального университета Малайзии за постоянную поддержку молодых ученых. Исследование выполнено при финансовой поддержке Университета Малайзии Теренггану.

Для цитирования: Че Сулейман Н. Ф., Аб-Хамид М. Ф., Ридзуан А. Р. Инклюзивный рост: комплексный подход к распределениюдоходов //Экономика региона. 2021.Т.17, вып. 1.С. 301-317. https://doi.org/10.17059/ekon.reg.2021-1-23

\section{Introduction}

Various efforts made by the Malaysian government to combat poverty have succeeded and gained international recognition in addressing poverty issues by the United Nation Development Program (UNDP). Population poverty has dropped from $49.3 \%$ in 1970 to $0.6 \%$ in 2014 , according to the Economic Planning Unit (EPU) ${ }^{1}$. However, it must be acknowledged that all sectors of society face the problem of the rising cost of living, especially the poor and disadvantaged in urban and rural areas. Those who belong to the lower-income group require special attention from the government to get them out of the poverty line by improving their standard of living and income. It is undeniable that income inequality will remain in a country and the community as the rich will exploit the poor so that the poor will continue to be mar-

\footnotetext{
${ }^{1}$ Economic Planning Unit (EPU). (2016). Report of Household and Basic Amenities Survey 2016.
}

ginalized from the country's development (Habito [1], McKinley [2]).

The Malaysian government has made many changes to the country's development policy by considering the concept of inclusiveness ranging from the New Economic Model, the 10th and 11th Malaysia Plans (10MP and 11MP, respectively) to address the issue of income inequality. However, the issue of inequality in income distribution is still debated to this day. Previous studies by Bulman [3], Flaaen [4] and Aiyar [5] found that middle high-income countries such as China, Malaysia and Thailand could no longer move up the ladder of economic growth. This is due to the gap in income distribution that will hinder economic growth. Furthermore, if government policies through income redistribution measures are not on the right track, then the middle-income trap will always be the problem in these three countries (Egawa [6]).

Based on the issues related to income distribution inequality discussed earlier, the Gini coef- 
ficients and measures of poverty rates alone are not sufficient to assess the well-being of people. Therefore, it is necessary to develop a more comprehensive measurement based on the concept of inclusive growth to measure social well-being. The inclusive growth index is used to develop the concept of inclusive growth that is the focus of national development policy in the 11th Malaysia Plan. Accordingly, Malaysia should focus on the transformation agenda to realize Vision 2020 (UNDP [7]). In Vision 2020, high-income communities are one of the key objectives. However, high income alone is not sufficient to achieve inclusive growth (MHDR [8]). As such, Malaysia needs to focus on new paradigms and establish community-based economies, help the lower income group, reduce their uncertainty and expand the middle-income households as indicators of inclusive growth (UNDP [7]).

Motivated by these issues, we examine the importance of equal income distribution and inclusive growth for the development of a country. While similar studies have been conducted in Asian countries (Klasen [9], McKinley [2] [10], Rauniyar and Kanbur [11], Ramos et al. [12]), no such study has been undertaken in Malaysia. We develop an index that measures inclusive economic growth using various dimensions apart from income such as expenditure, education, health, housing and employment aspects. We chose Malaysia because this middle-income country introduced the concept of inclusive growth in the national development plan. Besides, the concept of inclusive growth is the focus of national development policy in the $11 \mathrm{MP}$. As there are limited studies in Malaysia on the issue, this study contributes to filling the gap in the literature. Moreover, this inclusive growth index can be applied to measure the inclusiveness in other countries.

\section{Inequality Theory}

The relationship between growth and inequality has been widely debated. In 1955, Simon Kuznets found an inverted-U shaped curve between per capita income and cross-country inequality: as per capita income increased, the inequality would first widen and eventually improve. Key driving forces are considered as the structural changes due to the shift of the labour force from the poor and less productive traditional to the more productive and different modern sectors. Adelman and Morris [13], Paukert [14], Ahluwalia [15], and Robinson [16] supported the Kuznets' theory. However, Anand \& Kanbur [17] and Deininger \& Squire [18] has challenged the Kuznets inverted-U curve based on better data sets and tests in each country. For example, Deininger \& Squire [18] conducted a comprehensive test and confirmed that there was no evidence of the U-curve for each country. Overall, the complex relationship between growth and poverty is determined by the degree and extent of change in equality. Meanwhile, pro-poor growth is related to the relationship between these three elements: growth, poverty, and inequality.

According to Ali [19], rapid growth rates have contributed to an outstanding reduction of poverty incidence, accompanied by rising income, expenditure and non-income inequalities. Pro-poor growth approaches focus on the welfare of the poor to reduce inequality (Dinda [20]). The idea that higher inequality may result in under-investment in human capital by the poorer segments of society has also spurred a significant amount of research on the effect of inequality on social mobility and the allocation of talents across occupations (Banerjee \& Newman [21], Owen \& Weil [22], Maoz \& Moav [23], Hassler et al. [24]).

Meanwhile, high inequality may provide the incentives to work harder to invest and take advantage of high rates of return (Mirrlees [25], Lazear \& Rosen [26]). For example, if highly educated people are much more productive, the differences in rates of return may encourage more people to seek education. Higher inequality fosters aggregate savings, and therefore capital accumulation because the rich have a lower propensity to consume (Kaldor [27], Bourguignon [28]).

Nevertheless, the impact of inequality on growth has often been analysed based on a single measure of income inequality (typically, the Gini coefficient). However, the positive and negative theoretical mechanisms behind the links between inequality and growth might be rather associated with inequality in different parts of the income distribution (Voitchovsky [29]). Therefore, it is important to analyse the distribution based on multiple indicators apart from income such as consumption expenditure, housing, health, education and employment aspect (Stiglitz [30], ADB [31], Mc Kinley [10], Mlachila et al. [32]).

\section{Inclusive Growth Concepts and Debates}

Many studies have been conducted on inclusive growth, but similar to the concept of pro-poor growth, there is still no single definition of inclusive growth. Klasen [9] highlights that Inclusive Growth has been a strategic milestone for guiding the activities of the Asian Development Bank (ADB) in strategic operations. However, "there exists no clear definition or indicator to monitor the progress of inclusive growth at the coun- 
try, project, or program level” [9, p. 4]. While the debate continues, ongoing efforts towards creating a way to measure progress in inclusive growth have been reviewed and implemented through a framework analysis by Klasen [9], Ianchovichina \& Lundstrom [33] and McKinley [2].

Rauniyar \& Kanbur [11] have defined inclusive growth based on the inclusiveness concept necessary to increase equity in income distribution. The definition is similar to 'relative pro-poor growth', suggested by Grosse et al. [34]. Reviewing on their definition, Rauniyar \& Kanbur [11] point out that inclusive growth, which is a reduction in income inequality, can be more or less pro-poor growth depending on the income level of a country. They also argue that poverty reduction policy should focus on the growth that will increase the income of the lower-income group.

Inclusive growth is a growth that not only creates new economic opportunities but also ensures equal access to opportunities created for all people including the less fortunate and marginalized. Growth is inclusive when it allows all members of the community to participate in the process and contribute to the growth process irrespective of their individual circumstances (Ali \& Zhuang 2007 [35]). This is also in line with the findings of Stiglitz et al. [30], where inclusivity is considered in terms of not only income but also wealth and consumption expenditure. In addition, inclusivity takes into account non-economic indicators such as social stratification, education, health and job opportunities.

Proposals for measuring inclusivity and inequality have been discussed in Malaysia Human Development Report (MHDR) 2013 through the New Economic Paradigm, which distinguished four components of household capabilities (or purchasing power), namely, wealth effects, disposable income, leverage and transfers. Ramos et al. [12] have also used the concept of sharing and participation benefits. In their study, the benefits of sharing are represented by poverty and inequality, commonly used as an important indicator of pro-poor growth and inclusive growth. Simultaneously, employment-population ratio is used as a proxy for participation.

While past measures focused on reducing poverty and narrowing the income gap between ethnic groups, new priorities have emerged. Now the goal is to improve the household status. Following Stiglitz et al. [30], new measures of inclusivity should not only focus on income but also wealth and consumption expenditure. In addition, the measurement of income, consumption and wealth should be accompanied by indicators that reflect their distribution. New dimensions of inclusivity should also consider non-economic indicators such as social stratification, education, health and job opportunities.

Continuing the discussion on the incorporation of the non-income dimension, Rauniyar \& Kanbur [11] distinguish between two concepts, namely, inclusive growth and inclusive development. Inclusive growth refers to the distribution of income increases, while inclusive development refers to the distribution of multi-dimensional improvements as well as income. McKinley [2] and Klasen [9] also agree on the differences between inclusive growth and inclusive development. They argue that inclusive growth is limited to the dimensions of income, while inclusive development includes other dimensions besides income. However, McKinley [2] uses the term 'inclusive growth' similar to inclusive development despite the difference between the terms.

The concept of inclusive growth is more focused on the outcome of growth, in contrast to the concept of pro-poor growth. Klasen [9] notes that the difference between pro-poor growth and inclusive growth is based on the income recipient groups from growth. According to Klasen, "propoor growth focuses on people below the poverty line, while inclusive growth is arguably more general: it wants growth to benefit all stripes of society, including the poor, the near-poor, middle income groups, and even the rich" $[9$, p. 2]. This concept is related to the definition of inclusivity based on the distribution of growth. Dagdeviren et al. [36] noted the importance of issues regarding the role of income distribution in reducing poverty. According to them, if income redistribution is used to reduce poverty, the key policy to be considered is the mechanism of redistribution from whom, to whom and by what [36].

Inclusive growth involves fair growth or, in other terms, equity, indicating that the benefit of growth should be shared equally across the community. Thus, when growth benefits all societies, growth should not affect inequality because if this happens, more people will be affected. Klasen [9] brought a form of inclusivity concept of the nonzero amount. Based on this concept, the outcome of growth benefits not only one group but all societies, and the poor will benefit more. This concept is in line with the definition of inclusivity that not only includes certain groups of growth benefits but also benefits the less fortunate.

Ali \& Son [37] propose an alternative concept for inclusive growth involving the distribution, which shifts the policy focus from the outcome to opportunity. The authors suggest that growth 
is defined as inclusive if the growth improves the functioning of social opportunities that depend on: first, the average opportunity available to the community, and second, how the opportunity is shared to all societies [37]. While Ianchovichina \& Lundstrom [33] see inclusive growth as positive in terms of income, they emphasise the importance of rates and growth patterns, which are interconnected. For them, inclusive growth involves longterm sustainability and structural changes to diversify the economy and competition. Inclusive growth should also be broad-based across sectors and inclusive of most of the labour force in the country [33].

The African Development Bank (AfDB) also gives importance to the rate and growth pattern. Given that, high and sustainable long-term economic growth is necessary to reduce poverty and poverty and develop productive jobs. [38]. From this perspective, AfDB defines inclusive growth as "economic growth that results in a wider access to sustainable socio-economic opportunities for a broader number of people, regions or countries, while protecting the vulnerable, all being done in an environment of fairness, equal justice, and political plurality" [38, p. 2]. AfDB noted its difference from pro-poor growth, as inclusive growth provides opportunities for the whole community, instead of only taking care of the poor.

In line with Bhalla [39] as well as Ianchovichina \& Lundstrom [33], Klasen [9] also paid attention to the occurring growth processes. Klasen identified two possible focus points for determining inclusive growth episodes, namely, results and processes. The definition of inclusive growth is closely linked to the concept of pro-poor growth, which focuses on the outcome. The definition of inclusive growth incorporates an understanding of how the growth results are aligned with the income aspect. The growth aspect is considered and merged instead of being a substitute for the outcome aspect.

According to the International Policy Centre for Inclusive Growth (IPC-IG), inclusive growth is defined as participation and sharing benefits. This concept is in line with Kakwani \& Pernia [40]. Participation is related to active involvement in ensuring inclusive growth and outcome is the development of the number of productive individuals that contribute to the economy, demonstrated by the employment ratio. The benefits of sharing are specifically related to the distribution of outcome, which, in turn, affects the participation.

Ramos, Ranieri \& Lammens [12] also followed the concept of sharing and participation bene- fits. To measure inclusivity, the researchers developed the concept again by defining the variables as proxies for both dimensions. The benefits of sharing are represented by poverty and inequality, which are used as an important variable for propoor growth and inclusive growth. Meanwhile, the employment-population ratio is used as a proxy for participation that demonstrates the primary goal of involvement, though limited to the economic field.

Mello \& Dutz [41] show how to find a clear and concise definition of inclusive growth. Summing up the presentation and debate at the OECD 2011 conference, White [42] explained that inclusivity has been used in at least six different meanings. First, inclusivity is low-income inequality. Second, inclusivity means the absolute reduction of poverty. Third, inclusivity is the increase in economic growth. Fourth, inclusivity means reducing the income gap between North and South. Fifth, inclusivity is a reduction in inequality in opportunities, such as access to education, finance, and the judicial system. Sixth, inclusivity means to provide greater space for emerging economies in the governance of international financial institutions.

\section{Key Elements of Inclusive Growth}

As discussed earlier, the measurement of income distribution alone is not sufficient to illustrate the exact nature of income distribution that occurs in a country. Thus, we attempted to construct an index, namely, the Malaysia Inclusive Index (MII) that can measure inclusive economic growth in Malaysia. This study suggests an alternative way of measuring income distribution to achieve inclusive growth in Malaysia. We aim to construct an index that can complement the use of the Gini Index in measuring income distribution from a multi-dimensional perspective. This index can be used to assess more comprehensive distribution issues in Malaysia. With the establishment of this index, it is possible to analyse the inclusivity of distribution by using indicators that reflect the level of inclusive development in Malaysia.

To measure the level of inclusive development in Malaysia, several components have been selected and established based on the approaches adopted and adapted from the research of Stiglitz et. al [30] on inclusive development. The uniqueness of this index is the use of indicators representing the B40 household income group (lower class) by contrast with other inclusive indices developed by Ianchovichina \& Lundstrom [33], Rauniyar \& Kanbur [11], Ali \& Son [37], Bhalla [39], Son \& Kakwani [43] and McKinley [10]. 
Key Elements of Inclusive Growth

\begin{tabular}{|c|c|c|c|c|c|c|c|c|c|c|c|c|c|c|c|}
\hline & $\begin{array}{l}\sum_{\overline{0}}^{2} \\
\text { : } \\
0\end{array}$ & 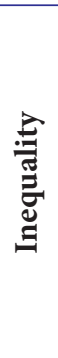 & 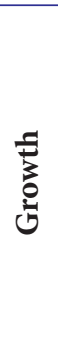 & 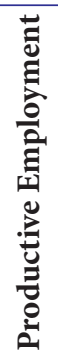 & 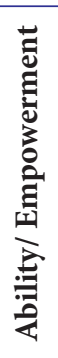 & 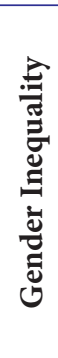 & 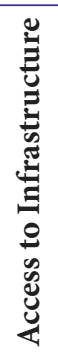 & 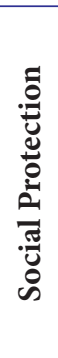 & 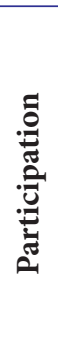 & 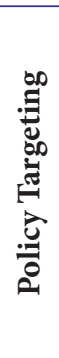 & 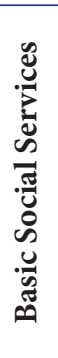 & 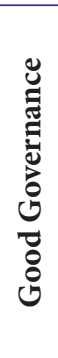 & 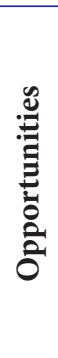 & 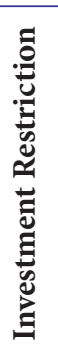 & 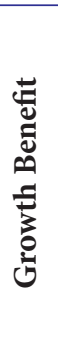 \\
\hline Klasen [9] & & $\mathrm{X}$ & & & & & & & & & & & $\mathrm{X}$ & & \\
\hline $\begin{array}{l}\text { Ianchovichina and } \\
\text { Lundstrom [33] }\end{array}$ & $\mathrm{X}$ & & $\mathrm{X}$ & $\mathrm{X}$ & & & & & & & & & & $\mathrm{X}$ & \\
\hline Rauniyar and Kanbur [11] & & $\mathrm{X}$ & $\mathrm{X}$ & & $\mathrm{X}$ & & & $\mathrm{X}$ & $\mathrm{X}$ & & & & $\mathrm{X}$ & & $\mathrm{X}$ \\
\hline $\begin{array}{l}\text { Groose, Harttgen and } \\
\text { Klasen [36] }\end{array}$ & $\mathrm{X}$ & $\mathrm{X}$ & & & $\mathrm{X}$ & & & & & & & & & & \\
\hline Ali and Son [37] & & $\mathrm{X}$ & & & & & & & & & & & $\mathrm{X}$ & & \\
\hline Bhalla [39] & $\mathrm{X}$ & & & $\mathrm{X}$ & $\mathrm{X}$ & & & & & & & & & & \\
\hline Kakwani and Pernia [40] & & $\mathrm{X}$ & & & $\mathrm{X}$ & & & & & $\mathrm{X}$ & & & & & \\
\hline Kakwani and Son [43] & $\mathrm{X}$ & $\mathrm{X}$ & $\mathrm{X}$ & & & & & & & & & & & & \\
\hline McKinley [10] & $\mathrm{X}$ & $\mathrm{X}$ & $\mathrm{X}$ & $\mathrm{X}$ & $\mathrm{X}$ & $\mathrm{X}$ & $\mathrm{X}$ & $\mathrm{X}$ & & & $\mathrm{X}$ & $\mathrm{X}$ & & & \\
\hline Ravallion and Chen [44] & $\mathrm{X}$ & & & & & & & & & & & & & & \\
\hline Habito [1] & $\mathrm{X}$ & & & & & & & & & & & & & & \\
\hline White and Anderson [45] & & $\mathrm{X}$ & & & & & & & & & & & & & \\
\hline $\begin{array}{l}\text { Kakwani, Khandker and } \\
\text { Son [46] }\end{array}$ & $\mathrm{X}$ & $\mathrm{X}$ & $\mathrm{X}$ & & & & & & & & & & & & \\
\hline Kraay [47] & $\mathrm{X}$ & $\mathrm{X}$ & & & & & & & & & & & & & \\
\hline
\end{tabular}

Source: Past Studies Compilation.

The index is important as an alternative and improvement to the Poverty Line Income (PLI) and the Gini Index that have been used to measure the level of poverty and income inequality in Malaysia. This study focuses on inclusive distribution according to the Malaysian government's agenda to strengthen inclusivity and establish equitable society. Therefore, these alternative measurements are expected to enable government policies that will help those affected and marginalized groups, especially the B40 income group. The implemented policies can help them equally enjoy the well-being, improve living standards and benefit from economic growth in Malaysia.

Improving B40 household status is important for the country, as currently in Malaysia, there are about 2.7 million B40 households with an average monthly income of RM 2,537 as the Economic Planning Unit 2016 reported. As Malaysia continues to develop, the B40 household income group should not be denied opportunities resulting from the country's prosperity. If the B40 household income group maintains its socioeconomic position, this situation will bring social costs to the country. The social costs, such as the reduction of the required number of skilled manpower will affect the growth of the country's output. In addition, this situation will also cause an increase in inequality in the urban areas that will also affect the potential for economic growth in rural and suburban areas. Employment opportunities, access to healthcare and education services, and a good social security network will ensure that B40 household income groups get the chance to enjoy a better life.

Hopefully, as the special attention is paid to the B40 income group, their income, wellbeing and quality of life will continue to grow in line with the country's economic development to achieve developed countries by 2020 . The B40 household income group, regardless of ethnicity, shall not be taken for granted, especially the poor and low-income households in urban and rural areas.

Table 1 shows that the most discussed key elements of inclusive growth mainly concern poverty, inequality, growth and ability or empowerment. Then, they are followed by key elements of productive employment and opportunities. Only a few literature sources discussed gender inequality, access to infrastructure, social protection, participation, policy targeting, basic social services, good governance, investment restriction and growth benefit. Therefore, the index components and in- 
Components and Indicators for the Malaysia Inclusive Index

\begin{tabular}{|l|l|}
\hline \multicolumn{1}{|c|}{ Component } & \multicolumn{1}{|c|}{ Indicators } \\
\hline Income & $\begin{array}{l}\text { Gross national income per capita (purchasing power parity) } \\
\text { Average monthly gross household income } \\
\text { Average income B40 and M40 interval }\end{array}$ \\
\hline Consumption Expenditure & $\begin{array}{l}\text { Household final consumption expenditure (\% of GDP) } \\
\text { General government final expenditure (\% of GDP) }\end{array}$ \\
\hline Housing & $\begin{array}{l}\text { House Price Index } \\
\text { Percentage of low-cost housing unit to the group B40 } \\
\text { Percentage of households with treated water } \\
\text { Percentage of households with electricity }\end{array}$ \\
\hline \multirow{3}{*}{ Education } & $\begin{array}{l}\text { High school participation rates } \\
\text { Tertiary education participation rate } \\
\text { School dropout rate }\end{array}$ \\
\hline Employment Aspect & $\begin{array}{l}\text { Life expectancy at birth } \\
\text { Under-five mortality rate (per 1,000 babies) } \\
\text { Total fertility rate }\end{array}$ \\
\hline
\end{tabular}

Source: Author's compilation.

dicators are cross-sectorial and overarching different key elements of inclusive growth. Every MII component will consider important factors and indicators that will reflect the B40 household income group in the formation of the index.

\section{Methodology}

Based on the above concepts and arguments from previous studies, we have selected and adopted several components of inclusive growth to study the situation in Malaysia. The components can be described in detail as below.

Country income will reflect the country's overall ability to generate wealth for its people. Income also represents the size of opportunity for the country to convert wealth into prosperity at aggregate level. Most of inequality studies focused on salary and income. However, to measure inequality in well-being, consumption expenditure is a more appropriate component. Conceptual arguments often favour consumption expenditure more than income as a better measure for material wellbeing. For example, consumption expenditure reflects more on long-term sources. Housing components are also important in determining inclusive economic growth, as they involve living and social wellbeing. Affordable houses equipped with basic facilities and amenities such as water and electricity are an important factor in ensuring the living conditions of a family and society are optimal.

Education is one of the most powerful instruments to reduce poverty and inequality; it is the basis for sustainable and inclusive economic growth. Education plays an important role in providing individuals with the knowledge, skills and competencies required to participate effectively in society and in the economy. Health is also one of the key components of inclusive growth. Physically and mentally healthy workers are more powerful and efficient. They are more productive and can earn higher wages. They are also less likely to apply for leave (due to their illness or illness in their families). In addition, aspects and job opportunities are one of the essential elements of inclusive growth. Increase in employment (i. e., the number of jobs) and productivity of employment (i. e., income from employment) is important for a sustainable growth strategy that leads to poverty reduction. This is because most of the poor consider labour the most important asset.

Therefore, the above arguments proved that these components are very important in the determination of inclusive growth. The Malaysia Inclusive Index is a composite index that includes six components. A total of 19 indicators were selected to represent the six components, as shown in Table 2 below.

\section{Selection of the Data}

The indicator selected for each component is an indicator that can represent the component and the availability of the indicator in the time series data. All indicators are marked as positive or negative. Positive indicators (such as life expectancy, literacy rate) mean that any increase in nu- 
merical value indicates a better condition. While indicators marked negative (such as infant mortality rates) show the opposite. For indicators marked negative, trends have been corrected to show the progress of well-being of life, while the downturn will show a deterioration of well-being of life. It is necessary to ensure that the reading flow for each component as well as for the composite index is the same.

Time series data is obtained from the following sources. Data for income and consumption expenditure components were derived from Bank Negara Malaysia (BNM) data, the Malaysian Economic Planning Unit (EPU) and the Department of Statistics, Malaysia (DOSM). Data on housing components were derived from data and statistics from the Ministry of Housing and Local Government (KPKT) as well as the National Property Information Centre (NAPIC). Data for educational components are obtained from the Ministry of Education Malaysia (MOE), Ministry of Higher Education (MOHE) and Malaysia Time Series Publication issued by the Department of Statistics, Malaysia (DOSM). For health components, the data were obtained from the Ministry of Health Malaysia (MOH) as well as Malaysia Time Series Publications. Employment component data were obtained from the Ministry of Human Resources (MOHR) via the Labour Force Survey (LFS) report as well as Malaysia Time Series Publication data.

This study also uses data from HIS and HES for many years. Data for HIS and HES were taken from 1990 to 2016 with two-year and five-year intervals. Incomplete data were interpolated using the moving average. For example, if the data in 1990 and 1992 were 100 and 120, the data for 1991 was calculated as $(100+120) / 2=110$. The results of the study were not sensitive to the other way of interpolation.

\section{Construction of the Index}

MII's construction includes two methods. First, the variable is standardized into the index on the same scale. Second, these indices are then grouped into a single index using the same weighting. The data used for MII covers 27 years (1990-2016). To enable comparison, the data used should be uniformed using the past track record for each indicator. The standard deviation method is used to measure the standards for each indicator. Standard deviation is used to standardize each indicator and allow the attribute to be summed up to generate a composite index. The standard deviation will determine the value of the frequency distribution around the average value with a higher level of precision. According to Chebyshev's theorem, regardless of the form of distribution, at least 75 percent of the value will fall in +2 standard deviations from the average distribution value and at least 89 percent of the value will be between +3 standard deviation.

The different variables described above represent different components in MII; the variables are not specified in the same unit. Therefore, this study needs to use the same unit for each component to construct the index. To address this issue, we used two methods: the $Z$-score approach, and the Min-Max approach. $Z$-scores are used to convert a variable to an average of $\mu$ and a standard deviation of $\sigma$ to the index score or $Z$-score that can be expressed as follows:

$$
Z=\frac{(X-\mu)}{\sigma} .
$$

With this standardization, all variables are expressed in the same unit, which is the standard deviation, and, therefore, can be summed up into a single index.

The Min-Max approach also consists of altering the variable $X$ into the index $Z$, following the formula:

$$
Z^{\prime}=\frac{\left(X-X_{\min }\right)}{\left(X_{\max }-X_{\min }\right)} .
$$

$X_{\min }$ and $X_{\max }$ each have the minimum (min) and maximum (max) $X$. The variable $Z^{\prime}$ differs from the $Z$ variable mentioned above as $Z^{\prime}$ has a value from 0 to 1 .

In this study, the index will be constructed using four weighting schemes, using one same weighting schemes and three different weighting schemes. This weighting scheme is drawn from previous studies that have constructed indexes for analysing the distribution and economic growth stages (Stiglitz [30], ADB [31], Mc Kinley [10], and Mlachila et al. [32]). The weighted schemes assigned to each component are as follows:

The Malaysia Inclusive Index will be constructed using a simulation method and these four weighting schemes. The weighting selection is based on the findings obtained after the index is formed. If the value of the indices formed using the four weighting schemes does not show a significant difference, the same weighting scheme will be selected in the formation of the Malaysia Inclusive Index. The same weight $\left(\gamma_{1}=\gamma_{2}=\gamma_{3}=\gamma_{4}=\gamma_{5}=\right.$ $=\gamma_{6}=16.7$ percent) will be given to six sub-components namely income, expenses, housing, education, health and employment aspect. We selected the same weighting scheme used in other wellknown indices such as the Human Development 
Index Weighting

\begin{tabular}{|l|c|c|c|c|}
\hline \multicolumn{1}{|c|}{ Component } & Scheme 1 & Scheme 2 & Scheme 3 & Scheme 4 \\
\hline Income & 0.167 & 0.5 & 0.3 & 0.2 \\
\hline Expenditure & 0.167 & 0.1 & 0.3 & 0.2 \\
\hline Housing & 0.167 & 0.1 & 0.1 & 0.1 \\
\hline Education & 0.167 & 0.1 & 0.1 & 0.2 \\
\hline Health & 0.167 & 0.1 & 0.1 & 0.1 \\
\hline Employment & 0.167 & 0.1 & 0.1 & 0.2 \\
\hline
\end{tabular}

Source: Author's calculation.

Index (HDI) or Economic Vulnerability Index (EVI) sue to its simplicity and transparency. However, as Guillaumont [48] emphasises, the same weighting scheme does not lead to the formation of biased indices, because the number of components found in the index determines the weighting.

Some aggregation alternatives (such as principal component analysis or regression-based approaches) are not suitable for this study. The principal component analysis is difficult to perform when the index has more than three variables. The inclusive index developed in the study has six components comprising 19 variables. In addition, the legitimacy of the regression-based approach depends entirely on the quality of regressions, particularly, issues related to the endogeneity of regressors.

\section{Index Calculation}

For the formation of the Malaysia Inclusive Index, we adapted the methods used for the establishment of the Malaysia Welfare Index (MWI) 2013 as well as Malaysia's Quality of Life Index (MQLI) 2010. These indices are designed to be a measurement that illustrates the situation in Malaysia. Adhering to this principle, inclusive growth is very important to the country because it is one of the most effective measures to assess the progress of a community. Inclusive growth is also an important determinant describing that the population of a country is enjoying a comfortable living standard. While there are various aspects and assessments to measure inclusive growth, in general, high levels of inclusivity can bring about the well-being of life. Evaluation of the development of a nation should not focus solely on economic aspects but should include other aspects that reflect the change in the quality of life of its people.

The method of index construction includes four main steps as follows. The process starts with the first step of calculating the standard score for each lead in year $i$. The second step is the calculation of sub-indices for each indicator in year $i$. The third step involves the calculation indices for each component in year $i$. Finally, the final indexing process, the fourth step is the calculation of the composite index in year $i$. The steps in the construction of the Malaysia Inclusive Index to measure inclusive economic growth in Malaysia are described in detail below.

First step: Estimated standard score for each indicator in year $i$.

\section{(i) Standard deviation}

The standard deviation is a statistic that reflects the distribution of indicator values across min in a dataset. When the values are close together, the standard deviation is small. When the values are dispersed, the standard deviation is relatively large. The formula for the standard deviation $\sigma$ for indicator $j$ is given as:

$$
\sigma_{k}=\sqrt{\frac{1}{N} \sum_{t=1}^{N}\left(x_{k t}-\mu_{k}\right)^{2}},
$$

where: $\sigma_{k}=$ standard deviation of the indicator $k$; $N=$ number of observations; $x_{k t}=k$ indicator value at time $t ; \mu_{k}=$ average indicator value $k$.

\section{(ii) Standard Score}

The standard score reflects observations in the form of standard deviation units above or below min (changes in observations) by subtracting average values and dividing them by the standard deviation. The calculation is as below:

$$
Z=\frac{x_{k t}+\mu_{k}}{\sigma}
$$

where: $x_{k t}=$ the value of the indicator $k$ at time $t$; $\mu=$ average indicator value; $\sigma=$ standard deviation for the data series; $z=$ standard scores.

Second step: Estimated sub-index for each indicator in year $i$.

\section{(i) Sub-Index for Positive Indicators}

The sub-index for each indicator for each year is obtained by multiplying the standard score by 10 and adding 100 as shown below. However, this can only be used for positive indicators such as life expectancy at birth and literacy rate, whose increase in numerical values shows an improvement of the situation.

$$
I_{t k}^{+}=100+z \times 10 \text {. }
$$


(ii) Sub-Index for negative indicator

For negative indicators, such as mortality rates, where an increase in numerical values indicates a decline, the sub-index calculations for the indicators have been adjusted. The trend for negative indicators has been corrected to have a consistent reading with the index by subtracting 100 rather than adding 100. Examples of negative indicators are infant mortality and unemployment rate, where an increase in numerical values indicates a deterioration in living conditions and well-being.

$$
I_{t k}^{-}=100+z \times 10 \text {. }
$$

(iii) Index with the year 2000 as the base year

Once this step is completed, to get the index value that can be compared to the starting year or the base value, the score should be divided by the base value. The value for the year 2000 will always be 100 .

$$
I_{2005 k}=\left(\frac{I_{t k}^{+/-}}{I_{2000 k}}\right) 100 .
$$

Third step: Estimates of the index for each component in Year $i$.

The index of each component is obtained using an average indicator value with the year 2000 base value for the component as follows:

$$
I_{d}=\frac{1}{N} \sum_{k=1} I_{t k},
$$

where: $I_{d}=$ component index; $N=$ number of indicators; $I_{t k}=$ the index value of indicator $k$ with the base year 2000 in year $t$.

Fourth step: Estimated composite index in Year $i$.

The Composite Index is obtained by calculating the average number of indices for each component.

$$
M I I=\frac{1}{N} \sum_{d=1} I_{d},
$$

where: $M I I=$ composite index; $I_{d}=$ component index; $N=$ number of components.

\section{Result and Findings}

This section describes the results of steps in the construction of the Malaysia Inclusive Index. The first two steps are to get the Standard Score and the Sub Index for each indicator. The next step is to obtain the Base Year Index before the Index of Each Component can be constructed.

Generally, the index value of each indicator with the base year 2000 shows year-on-year growth from 1990 to 2016. Although some indicator indices are demonstrating a downward and upward trend, most indicators show an increase, indicating that the components of income, hous- ing, education, health and employment are gaining momentum in Malaysia. In this section, we will explain the findings concerning the indices of each component of the Malaysia Inclusive Index. Table 4 shows the findings for the indices of each component using the year 2000 as the base year. As can be seen in Table 4, each Component Index increases from time to time, demonstrating an increase in the level and quality of each component in the Malaysia Inclusive Index.

This section begins by analysing trends for each selected indicator as a component of the Malaysian Inclusive Index. For the income component, the gross national income per capita (GNI) the average monthly gross household income (HHINC) indicators showed an increase in the period from 1990 to 2016. Simultaneously, the gap in the average gross income between the B40 (lower class) and M40 (middle class) household groups (GAP) increased from 1990 to 2016. Then, in 2000, the GAP declined dramatically to 87,945 from 117,278 in 1999 . The GAP indicator then showed year-by-year increase from 2000 to 2016. This further reinforces the fact that the M40 and T20 (upper class) household income grew larger than the B40 household income. The components of income represented by household and national income are improving.

For components of expenditure, the household final consumption expenditure (HHEX) and the general government final expenditure (percent of GDP) (GOVEXP) showed a downtrend and upward trend from 1990 to 2016. The housing component comprises four indicators, namely, the Malaysia House Price Index (HPI), the percentage of low-cost housing units to the B40 (LCOST), the percentage of households with treated water (WATER), and the percentage of households with electricity (ELECTR). The HPI Indicator showed an upward trend from 1990 to 1997, but experienced a decline in the world economic crisis from 1998 to 1999. HPI indicators showed an increasing trend from 2000 to 2016. Moreover, indicators such as LCOST, WATER and ELECTR showed an upward trend during the period from 1990 to 2016.

While the expenditure component index showed a downtrend and upward trend over the period, the components of income showed an increase of 24.623 percent in 2016 with an index value of 124.623 compared to the base year 2000 . Meanwhile, comparisons showed that the index value increased by 26.888 percent in 2016 compared to 1990 with the index value of 97.735 . Most surprisingly, the components of the expenditure showed a decline of 2.012 percent in 2016 with an index value of 129.989 compared to the begin- 
ning of the study (1990) with the index value of 132.001. Nevertheless, the expenditure component showed an increase of 29.989 percent in 2016 compared to the base year 2000 .

The housing component showed an increase of 18.872 percent in 2016 with the index value of 118.872 compared to the base year 2000 . Meanwhile, the housing component showed an increase of 31.411 percent in the year 2016 compared to 1990 with index value only at 87.461 . This result indicated that, in the context of Malaysia, the main component of household spending apart from food and non-alcoholic beverages is housing, water, electricity, gas and fuel. Housing prices in Malaysia shown a sharp increase from 1990 to 2016. This situation illustrates that the B40 household is improving its standard of living by having proper housing conditions, electricity and water facilities.

The education component comprises three indicators, namely, higher school participation rate (SECON), tertiary education participation rate (TER) and school dropout rate (DROP). The three indicators, SECON, TER and DROP show an upward and downward trend over the period 1990 to 2016. Furthermore, the components of education showed an increase of 6.926 in 2016 with an index value of 106.926 compared to the base year 2000 . The education index showed a significant increase in 2016 compared to 1990 at 82.931 with an increase of 23.995 percent. Therefore, this result further strengthens the fact that the education level in Malaysia has shown a significant increase from 1990 to 2016. The school dropout rate has declined significantly from 1990 to 2016, demonstrating that education is for all, regardless of age and ethnicity. Malaysia is moving towards a better future with educated human capital.

The health component included three indicators, namely, life expectancy at birth (LEXPEC), under-five mortality rates (per 1,000 babies) (MORTAL), and total fertility rate (FERTI). The LEXPEC, MORTAL and FERTI indicators were increasing year by year from 1990 to 2016. The health component index showed an increase of 13.896 percent in 2016 with an index value of 113.896 compared to the base year 2000. The health component index also showed a high increase in 2016, which was 31.238 percent compared to 1990, which had an index value of 82.658. This fact indicates that health status in Malaysia has improved from 1990 to 2016. Households in Malaysia (B40, M40 as well as T20) showed a significant increase in life expectancy, going from 70.86 years in 1990 to 75.65 years in 2016. Meanwhile, the fertility rate has declined sharply in 26 years, from 3.55 in 1990 to 2.04 in 2016. This situation illustrates that the Malaysian household is improving its standard of living by maintaining a healthy lifestyle. The increase in the average age of mothers at first birth indicates a shorter reproductive period in women. Meanwhile, changes in the age structure of the population lead to an increase in the number and mortality rate in Malaysia.

The employment component has four indicators, namely, the labour force participation rate (EMPLY), unemployment rate (UNEMP), the ratio of skilled workers to non-skilled workers (SKILL) and percentage unskilled workers (UNSKILL). All four indicators showed an upward trend from 1990 to 2016. In addition, the employment component index showed an increase of 12.834 percent in 2016 with an index value of 112.834 compared to the base year 2000. Meanwhile, the employment aspect index showed an increase of 24.298 percent with the index value of 88.536 in 1990 compared to 2016. The employment aspect components showed the least improvement compared to other components due to various factors. The factors include rising unemployment rates, increasing demand for skilled workers compared to nonskilled workers who are increasingly becoming a topic of discussion in government policy formulation. When non-skilled workers are replaced with automated machines and hardware, employment opportunities are decreasing. This situation will make income distribution in the country less equal and will affect those in need, especially among the B40 household income group.

Overall, the indices of the components for income, housing, education, health, and employment showed improvement throughout the period from 1990 to 2016. The overall improvement in the index values of the components of income, expenditure, housing, education, health and employment aspects indicates that economic growth in Malaysia is increasingly inclusive and fair. The new index proposed in this research that measures the inclusiveness have taken into account several important dimension apart from the traditional approach, which focuses solely on the income dimension. This new index includes expenditure, education, health, housing, and employment aspects dimensions to measure inclusivity. Therefore, economic growth in the country should be measured based on these components to ensure that all households regardless of their income level share inclusive and equal opportunity. This index differs from the traditional approach (income distribution) that only evaluates household income level to measure their standard of living and economic growth. Thus, this new index can 
Table 4

Indices for Each Component

\begin{tabular}{|c|c|c|c|c|c|c|}
\hline Year & Income & Expenditure & Housing & Education & Health & Employment Aspect \\
\hline 1990 & 97.735 & 132.001 & 87.461 & 82.931 & 82.658 & 88.536 \\
\hline 1991 & 99.248 & 132.023 & 89.141 & 83.942 & 84.422 & 91.635 \\
\hline 1992 & 100.738 & 125.403 & 90.531 & 84.927 & 86.059 & 94.799 \\
\hline 1993 & 102.558 & 120.324 & 91.748 & 84.191 & 87.681 & 98.252 \\
\hline 1994 & 104.352 & 118.100 & 93.063 & 84.607 & 89.213 & 98.112 \\
\hline 1995 & 106.218 & 118.366 & 94.826 & 84.912 & 90.679 & 97.901 \\
\hline 1996 & 109.487 & 108.579 & 96.504 & 89.567 & 92.124 & 100.574 \\
\hline 1997 & 112.582 & 105.696 & 97.661 & 90.245 & 93.786 & 101.356 \\
\hline 1998 & 111.021 & 94.513 & 97.947 & 98.366 & 95.653 & 98.706 \\
\hline 1999 & 110.266 & 101.187 & 98.755 & 99.237 & 97.822 & 97.866 \\
\hline 2000 & 100.000 & 100.000 & 100.000 & 100.000 & 100.000 & 100.000 \\
\hline 2001 & 100.789 & 113.816 & 100.803 & 101.166 & 102.125 & 101.728 \\
\hline 2002 & 101.893 & 117.145 & 102.169 & 104.074 & 103.806 & 102.170 \\
\hline 2003 & 102.865 & 116.544 & 104.107 & 106.292 & 105.109 & 101.437 \\
\hline 2004 & 103.941 & 113.548 & 106.435 & 101.482 & 106.263 & 101.931 \\
\hline 2005 & 105.044 & 107.796 & 108.169 & 105.312 & 107.159 & 101.809 \\
\hline 2006 & 106.305 & 106.351 & 109.669 & 102.302 & 107.843 & 102.448 \\
\hline 2007 & 107.910 & 109.768 & 110.976 & 104.154 & 108.489 & 102.764 \\
\hline 2008 & 108.916 & 108.753 & 112.011 & 105.318 & 109.034 & 101.401 \\
\hline 2009 & 109.370 & 123.445 & 112.653 & 105.458 & 109.607 & 100.964 \\
\hline 2010 & 111.103 & 119.797 & 113.298 & 106.668 & 110.208 & 102.575 \\
\hline 2011 & 113.069 & 123.334 & 114.591 & 105.804 & 110.835 & 106.118 \\
\hline 2012 & 114.852 & 129.005 & 115.844 & 107.258 & 111.342 & 108.365 \\
\hline 2013 & 117.312 & 131.585 & 116.853 & 107.426 & 111.933 & 111.313 \\
\hline 2014 & 119.964 & 130.397 & 117.799 & 108.074 & 112.607 & 113.539 \\
\hline 2015 & 122.375 & 131.903 & 118.324 & 107.500 & 113.252 & 113.681 \\
\hline 2016 & 124.623 & 129.989 & 118.872 & 106.926 & 113.896 & 112.834 \\
\hline
\end{tabular}

Source: Author's own calculation.

be applied to other countries using the same indicators and components to reflect the level of the country's economic growth.

\section{Malaysia Inclusive Index}

The Malaysia Inclusive Index (MII) comprises six components. These components are important in determining the level of inclusivity in Malaysia. Table 5 shows the Malaysia Inclusive Index for the period from 1990 to 2016 using the same weight and several different weights. The first weighting scheme uses the same weighting to the six components. Meanwhile, the second weighting scheme provided a bigger weight on one component, namely, the income component with a weight of 0.5 , while other components such as expenditure components, education, housing, health, and employment opportunities had the same weight of 0.1 . The third weighing scheme puts greater weight on two components, namely the components of income and expenditure of 0.3 per component. The components of housing, health, education, and job opportunities were equal to 0.1 .
The fourth weighting scheme provides 0.2 weightings to the components of income, expenditure, education and employment opportunities. The housing and health components received a weight of 0.1 . The weighting selection is based on past studies as developed by McKinley [2], Stiglitz et al. [49] and Coskun et al. [50].

Overall, the findings show that the Malaysia Inclusive Index has improved from 1990 to 2016 despite using four different weighting schemes. The results of the index construction using four different weights showed similar results. As shown in Table 5, the index values formed do not show significant changes despite the same weighting schemes and different weighting schemes applied. Therefore, this study uses the same weighting schemes to the Malaysia Inclusive Index. The main rationale for selecting the same weighting scheme lies in its simplicity and transparency. The same weight has been used in other well-known indexes such as the Human Development Index (HDI) or Economic Vulnerability Index (EVI). 
Malaysia Inclusive Index

\begin{tabular}{|c|c|c|c|c|}
\hline \multirow{2}{*}{ Year } & \multicolumn{4}{|c|}{ Weighting Scheme } \\
\hline & 1 & 2 & 3 & 4 \\
\hline 1990 & 95.220 & 96.226 & 103.079 & 97.253 \\
\hline 1991 & 96.735 & 97.740 & 104.295 & 98.726 \\
\hline 1992 & 97.076 & 98.541 & 103.474 & 98.832 \\
\hline 1993 & 97.459 & 99.499 & 103.052 & 99.008 \\
\hline 1994 & 97.908 & 100.485 & 103.235 & 99.262 \\
\hline 1995 & 98.817 & 101.778 & 104.207 & 100.030 \\
\hline 1996 & 99.472 & 103.478 & 103.297 & 100.504 \\
\hline 1997 & 100.221 & 105.165 & 103.788 & 101.120 \\
\hline 1998 & 99.368 & 104.029 & 100.727 & 99.881 \\
\hline 1999 & 100.856 & 104.620 & 102.804 & 101.369 \\
\hline 2000 & 100.000 & 100.000 & 100.000 & 100.000 \\
\hline 2001 & 103.405 & 102.358 & 104.964 & 103.793 \\
\hline 2002 & 105.209 & 103.883 & 106.933 & 105.654 \\
\hline 2003 & 106.059 & 104.781 & 107.517 & 106.349 \\
\hline 2004 & 105.600 & 104.936 & 106.858 & 105.450 \\
\hline 2005 & 105.881 & 105.546 & 106.097 & 105.525 \\
\hline 2006 & 105.820 & 106.014 & 106.023 & 105.233 \\
\hline 2007 & 107.344 & 107.570 & 107.942 & 106.866 \\
\hline 2008 & 107.572 & 108.110 & 108.077 & 106.982 \\
\hline 2009 & 110.249 & 109.898 & 112.713 & 110.073 \\
\hline 2010 & 110.608 & 110.806 & 112.545 & 110.379 \\
\hline 2011 & 112.292 & 112.603 & 114.656 & 112.208 \\
\hline 2012 & 114.444 & 114.607 & 117.438 & 114.614 \\
\hline 2013 & 116.070 & 116.567 & 119.422 & 116.406 \\
\hline 2014 & 117.064 & 118.224 & 120.310 & 117.436 \\
\hline 2015 & 117.839 & 119.654 & 121.559 & 118.250 \\
\hline 2016 & 117.857 & 120.563 & 121.636 & 118.151 \\
\hline
\end{tabular}

Source: Author's own calculation.

Referring to Table 5 below, in the first weighting scheme where all weights were equal, the Malaysia Inclusive Index increased to 117.857 in 2016 compared to the base year 2000 which showed an increase of 17.857 percent over 17 years. In addition, the Malaysia Inclusive Index in 1990 only recorded 95.220 and showed an increase of 22.637 percent to 117.857 in 2016 over 27 years. This proves that economy in Malaysia is growing rapidly and inclusively in line with the government policy, which emphasizes the development and growth of the economy inclusively.

\section{Discussion}

The findings of this study are also aligned with the concepts and theories presented by some previous researchers in their study. Klasen [9] brought a form of inclusivity concept of the nonzero amount. Based on this concept, the outcome of growth benefits not only one group, but also all societies, and the poor will benefit more. This concept is in line with the definition of inclusiv- ity stating that growth benefits not only certain groups but also the less fortunate group.

It is also in line with the UNDP 2014 report, on which Malaysia relies to define the transformation agenda that will lead to the realization of Vision 2020. MHDR's focus on inclusive growth and its ambition to contribute "Redesigning an Inclusive Future" offers an opportunity for collective remodelling for the future where growth and high income alone are insufficient. What Malaysia needs now is to focus the economy on new paradigms. These include the establishment of community-based economies, support of the lower income group, reduction of their uncertainty and expansion of the middle-income households as indicators of inclusive growth (UNDP ${ }^{1}$ )

The African Development Bank (AfDB) has stated that inclusive growth is an economic

\footnotetext{
${ }^{1}$ United Nations Development Programme. (2013). Malaysian Human Development Report : Redesigning Inclusive Future: UNDP Malaysia, pp. 1-8.
} 
Growth and Distribution Policy in Malaysia, 1970-2015

\begin{tabular}{|c|c|c|}
\hline Growth Rate & Policy Priority & Period, \% \\
\hline $1955-1970$ & Growth & 6.5 \\
\hline $1971-1985$ & Distribution & 7.7 \\
\hline $1986-2000$ & Growth & 5.0 \\
\hline $2001-2015$ & Distribution & $5.0-6.0$ \\
\hline $2016-2030$ & Inclusive and Sustainable Growth & \\
\hline
\end{tabular}

Source: Malaysia Human Development Report 2013.

growth, which enables greater access to sustainable socio-economic opportunities for more communities, regions or countries. In addition, inclusive growth protects vulnerable groups, in a fair environment, and political pluralism (AfDB [38]). In addition, the International Policy for Inclusive Growth (IPC-IG) brings the concept of inclusive growth as participation and sharing benefits. This concept is consistent with Kakwani \& Pernia [40], Ramos et al. [12] who also supported the concept of sharing and participation benefits.

Inclusive growth not only creates new economic opportunities but also ensures equal access to opportunities created for all groups including the less fortunate and marginalized. Growth is inclusive when it allows all members of the community to participate in and contribute to the growth process on the same track irrespective of their circumstances (Ali \& Zhuang [35]). This is also in line with the findings of Stiglitz et al. [30], who considered inclusivity in terms of not only income but wealth and consumption expenditure, analysing non-economic indicators such as social stratification, education, health and employment.

This is evidenced and supported by government policy for growth and distribution in Malaysia shown in Table 6. For the period from 1986 to 2000 , policy focused on economic growth, which registered a growth of 7 percent over the period. Meanwhile, for the next period of 2001 to 2015, the priorities were distribution and growth rates recorded at 5 percent compared to 7 percent in the previous period. Then, for the 2016-2030 period, the government has prioritised policies that focus on sustainable and inclusive growth. The government has targeted economic growth rates of 5 to 6 percent during the period. Hence, the findings from the Malaysia Inclusive Index study are supported by Malaysia's growth and distribution policies as shown below.

Thus, the Malaysia Inclusive Index demonstrates that Malaysia is at an excellent level, showing an increase in the value of the index year by year from 1990 to 2016. This measurement is important as it can provide clarification to the government and the responsible party on the economic situation experienced by the people Malaysia today. However, if these measurements are taken and applied in the policy development process, the components that show upward and downward trends and components that exhibit improvements such as education, health and employment components should be given more attention to ensure that every citizen gets a fair share of income and wealth of the country. The wealth of a nation should be shared to make Malaysia an inclusive growth country. In addition, the development and wealth of the nation should not ignore the less fortunate groups such as the B40 household income, the near-poor and poor.

\section{Conclusion}

Based on the above objectives and questions, a new measurement in the form of the Malaysia Inclusive Index has been constructed based on six components to measure the level of inclusive growth in Malaysia. Overall, the index has shown encouraging improvements in the period from 1990 to 2016. The indices for each component, the income index, housing index, education index, health index, as well as the employment aspect index showed a year-on-year increase from 1990 to 2016. This shows that the level of inclusiveness in Malaysia is increasing and improving year after year. The expenditure index experienced an upward and downward trend caused by government policy during the global economic crisis in 1998 and 2008.

The need to take a more holistic approach to measuring inequality and inclusivity is necessary for Malaysia and other countries in general. Therefore, this study has set up a new measurement to estimate the level of inclusiveness that considers various aspects and components besides income. Components such as consumption expenditure are very important as vulnerable groups and the B40 income group spend 60 percent of total expenditure on food, housing and transport $\left(\mathrm{EPU}^{1}\right)$. In addition, education, housing, health

\footnotetext{
${ }^{1}$ Economic Planning Unit. (2014). Household Expenditure Survey (HES) 2014. Retrieved from: https://www.dosm.gov.my/
} 
and employment are key factors and determinants in measuring the level of inclusiveness in Malaysia and are included as components in the construction of the index. This is because the Gini coefficient that considers income components alone is not sufficient to illustrate the standards and quality of life and the well-being of households. The quality of life and well-being cover many aspects and factors to ensure optimal living conditions of households. Such factors include consumption expenditure, housing, health, education, and employment aspects.

The Malaysia Inclusive Index implied that the main feature of inclusive growth is the benefit of the country's economic growth that should be shared by all segments of society. Malaysia's economic growth and development should benefit all people. The declining rate of inequality and poverty should be appropriate and in line with economic development. The rate of economic growth in Malaysia is high, sustainable, and resilient. Malaysia recorded a growth rate of 7.6 percent during the period 1970 to 2012 (household income grew by 7.3 percent over the same period) and was among the highest in the region as recorded by the IMF World Economic Outlook report in 2012.

v1/index (Date of access: 05.07.2020).
This fact suggests that Malaysia's inclusive policy has not hurt the economy. Resilient economic growth is supported by strong investment activity, with an average investment ratio to GDP of about 30 percent during the period 1970 to 1990, and remains at a similar level even if the measures are stretched longer for 2012. High and sustainable growth rates supported by strong investment activity has created new job opportunities. This situation led to a decrease in the unemployment rate from 7.4 percent in 1970 to about 3 percent in 2012. Comparison of cross-sectional studies shows that the unemployment rate in Malaysia is relatively low compared to regional countries, and is lower than in most developed economies (International Monetary Fund (IMF ${ }^{1}$ ); International Labor Organization $\left(\mathrm{ILO}^{2}\right)$; and World Bank ${ }^{3}$ ).

\footnotetext{
1 International Monetary Fund. (2012). World Economic Outlook Update. Washington DC (October). Retrieved from: http://www.imf.org/ (Date of access: 05.06.2020).

${ }^{2}$ International Labour Organization. (2012). World of Work Report 2012: Better Jobs for a Better Economy, International Labour Office, International Institute for Labour Studies. Geneva, pp. 3-9.

${ }^{3}$ World Bank. (2010). Malaysia Economic Monitor: Inclusive Growth. World Bank, pp. 64-67.
}

\section{References}

1. Habito, C. F. (2009). Patterns of Inclusive Growth in Developing Asia: Insights from an Enhanced Growth-Poverty Elasticity Analysis. ADBI Working Paper Series, No. 145. Tokyo, Asian Development Bank Institute, 55.

2. McKinley, T. (2010). Inclusive Growth Criteria and Indicators: An Inclusive Growth Index for Diagnosis of Country Progress. ADB Sustainable Development Working Paper Series, Asian Development Bank, 36.

3. Bulman, D., Eden, M. \& Nguyen, H. (2014). Transitioning from Low-Income Growth to High Income Growth. Is There a Middle Income Trap? Policy Research Working Paper No. 7104. World Bank, Washington DC, 30.

4. Flaaen, A., Ghani, E. \& Mishra, S. (2013). How to Avoid Middle Income Traps? Evidence from Malaysia. Policy Research Working Paper Series No. 6427. Washington, DC: World Bank, 7.

5. Aiyar, S., Duval, R., Puy, D., Wu, Y. \& Zhang, L. (2013). Growth Slowdowns and the Middle Income Trap. IMF Working Paper No. \#WP/13/71. March. Washington, DC: International Monetary Fund, 63.

6. Egawa, A. (2013). Will Income Inequality Cause Middle-Income Trap in Asia. Bruegel Working Paper, 26.

7. United Nations Development Programme. (2014). Human Development Report: Sustaining Human Progress: Reducing Vulnerability and Building Resilience. United Nations Development Programme, New York, 227.

8. Malaysia Human Development Report. (2013). Redesigning an Inclusive Future. United Nations Development Report, United Nations Development, Malaysia, 334.

9. Klasen, S. (2010). Measuring and Monitoring Inclusive Growth: Multiple Definitions, Open Questions, and Some Constructive Proposals. ADB Sustainable Development Working Paper Series, No. 12. Mandaluyong City, Philippines, Asian Development Bank, 15.

10. McKinley, T. (2011). Inclusive Growth Criteria and Indicators: An Inclusive Growth Index for Diagnosis of Country Progress. ADB Sustainable Development Working Paper Series, No. 14. Mandaluyong City, Philippines, Asian Development Bank, 36.

11. Rauniyar, G. \& Kanbur, R. (2010). Inclusive Development: Two Papers on Conceptualization, Application, and the ADB Perspective. Mandaluyong City, Philippines, Asian Development Bank, 45.

12. Ramos, R. A., Ranieri, R. \& Lammens, J. W. (2013). Mapping Inclusive Growth in Developing Countries. IPC-IG Working Paper, No. 105. Brasília, International Policy Centre for Inclusive Growth.

13. Adelman, I. \& Morris, C. T. (1971). Economic Growth and Social Equity in Developing Countries. Stanford University Press, Stanford, CA: 257 pages, 257. 
14. Paukert, F. (1973). Income Distribution at Different Levels of Development: A Survey of Evidence. International Labour Review, 108(2), 97-125.

15. Ahluwalia, M. S. (1974). Income Inequality: some dimensions of the problem. In: H. Chenery et al., Redistribution with Growth (pp. 3-37). Oxford University Press, Oxford.

16. Robinson, S. (1976). Sources of Growth in Less Developed Countries. Quarterly Journal of Economics, 85(3), 391408.

17. Anand, S. \& Kanbur, S. M. R. (1984). The Kuznets Process and the Inequality Development Relationship. Journal of Development Economics, 40, 25-52.

18. Deininger, K. \& Squire, L. (1996). Measuring income inequality: a new data-base. World Bank Economic Review, 10(3), 565-591.

19. Ali, I. (2007). Inequality and the Imperative for Inclusive Growth in Asia. Asian Development Review, 24(2), 1-16.

20. Dinda, S. (2014). Inclusive growth through creation of human and social capital. International Journal of Social Economics, 41(10), 878-895.

21. Banerjee, A. V. \& Newman, A. F. (1993). Occupational Choice and the Process of Development. Journal of Political Economy, 101(2), 274-98.

22. Owen, A. L. \& Weil, D. N. (1998). Intergenerational earnings mobility, inequality and growth. Journal of Monetary Economics, 41(1), 71-104.

23. Maoz, Y. D \& Moav, O. (1999). Intergenerational Mobility and the Process of Development. Economic Journal, 109(458), 677-697.

24. Hassler, J., Mora, J. V. R. \& Zeira, J. (2007). Inequality and Mobility. Journal of Economic Growth, 12(3), $235-259$.

25. Mirrlees, J. A. (1971). An exploration in the theory of optimum income taxation. Review of Economic Studies, 38, $175-208$.

26. Lazear, E. \& Rosen, S. (1981). Rank-Order Tournaments as Optimum Labor Contracts. Journal of Political Economy, 89(5), 841-864.

27. Kaldor, N. (1956). Alternative Theories of Distribution. Review of Economic Studies, 23, 83-100.

28. Bourguignon, F. (1981). Pareto Superiority of Unegalitarian Equilibrium in Stiglitz's Model of Wealth Distribution with Convex Saving Function. Econometrica, 49, 1469-1475

29. Voitchovsky, S. (2005). Does the Profile of Income Inequality Matter for Economic Growth? Distinguishing between the Effects of Inequality in Different Parts of the Income Distribution. Journal of Economic Growth, 10(3), $273-296$.

30. Stiglitz, J. E., Sen, A. \& Fitoussi, J.-P. (2009). Report by the Commission on the Measurement of Economic Performance \& Social Progress. Paris. Retrieved from: http://www.stiglitzsenfitoussi.fr/documents/rapport_anglais.pdf (Date of access: 05.07.2020)

31. Asian Development Bank. (2012). Asian Development Outlook 2012: Confronting Rising Inequality in Asia. Mandaluyong City, Philippines, Asian Development Bank, 272.

32. Mlachila, M., Tapsoba, R. \& Tapsoba, S. J. A. (2014). A Quality of Growth Index for Developing Countries: A Proposal. IMF Working Paper, 32.

33. Ianchovichina, E. \& Lundstrom, S. (2009). Inclusive Growth Analytics: Framework and Application. Policy Research Working Paper, No. 4851. Washington, DC, World Bank, 40.

34. Grosse, M., Harttgen, K. \& Klasen, S. (2008). Measuring Pro-Poor Growth in Non-Income Dimensions. World Development, 36(6), 1021-1047.

35. Ali, I. \& Zhuang, J. (2007). Inclusive Growth toward a Prosperous Asia: Policy Implications. ERD Working Paper Series No. 97. Manila: Asian Development Bank, 33.

36. Dagdeviren, H., van der Hoeven, R. \& Weeks, J. (2000). Redistribution matters: Growth for Poverty Reduction. Employment Paper, No. 2000/10. Geneva, International Labour Organization, 36.

37. Ali, I. \& Son, H. H. (2007). Measuring Inclusive Growth. Asian Development Review, 24(1), 11-31.

38. African Development Bank. (2012). Briefing Notes for AfDB's Long-Term Strategy - Briefing Note 6: Inclusive Growth Agenda. African Development Bank, Tunisia, 9.

39. Bhalla, S. (2007). Inclusive Growth? Focus on Employment. Social Scientist, 35(7/8), 24-43.

40. Kakwani, N. \& Pernia, E. (2000). What is Pro-poor Growth? Asian Development Review: Studies of Asian and Pacific Economic Issues, Vol. 18, No. 1. Mandaluyong City, Philippines, Asian Development Bank, 16.

41. de Mello, L. \& Dutz, M. A. (Eds.) (2012). Promoting Inclusive Growth: Challenges and Policies. Paris, OECD Publishing, 285.

42. White, W. R. (2012). Policy debate: How do you make growth more inclusive? In: L. de Mello, M. A. Dutz (Eds.), Promoting Inclusive Growth: Challenges and Policies (pp. 279-283). Paris, OECD Publishing, 279-283.

43. Kakwani, N. \& Son, H. H. (2006). Pro-Poor Growth: The Asian Experience. Research Paper 2006/56. Helsinki: UNUWIDER., 21.

44. Ravallion, M. \& Chen, S. (2003). Measuring Pro-poor Growth. Economics Letters, 78, 93-99.

45. White, H. \& Anderson, E. (2001). Growth versus Distribution: Does the Pattern of Growth Matter. Development Policy Review, 19(3), 267-289.

46. Kakwani, N., Khandker, S. \& Son, H. H. (2004). Pro-poor Growth: Concepts and Measurement with Country Case Studies. IPC-IG Working Paper, No. 1. Brasília, International Policy Centre for Inclusive Growth. 
47. Kraay, A. (2004). When Is Growth Pro-Poor? Cross-Country Evidence. IMF Working Paper, No. 4-47. Washington, DC, International Monetary Fund, 34.

48. Guillaumont, P. (2009). An Economic Vulnerability Index: its Design and its Use for International Development Policy. UNU-WIDER Research Paper 2008/99, forthcoming in Oxford Development Studies, Vol. 37, No. $3,32$.

49. Stiglitz, J. (2012). The Price of Inequality. New York: W.W. Norton, 560.

50. Seven, U. and Coşkun, Y. (2016). Does financial development reduce income inequality and poverty? Evidence from emerging countries. Emerging Markets Review, 26(C), 34-63.

\section{About the authors}

Nor Fatimah Che Sulaiman - Senior Lecturer,_Faculty of Business, Economics and Social Development, Universiti Malaysia Terengganu; https://orcid.org/0000-0001-8323-6876 (Kuala Nerus, Terengganu, 21030, Malaysia; e-mail: n.fatimah@umt.edu.my).

Mohd Fahmee Ab-Hamid - Multimedia University (Cyberjaya, 63100, Malaysia).

Abdul Rahim Ridzuan - Senior Lecturer, Faculty of Business and Management, Universiti Teknologi MARA (Melaka, 78000, Malaysia).

\section{Информация об авторах}

Че Сулейман Нор Фатима - старший преподаватель, факультет бизнеса, экономики и социального развития, Университет Малайзии Теренггану; https://orcid.org/0000-0001-8323-6876 (Малайзия, 21030, Куала-Нерус, Теренггану; e-mail: n.fatimah@umt.edu.my).

Аб-Хамид Мохд Фахми - Мультимедийный университет MMU (63100 Суberjaya, Малайзия, 63100, г. Сайберджая).

Ридзуан Абдул Рахим - старший преподаватель, факультет бизнеса и менеджмента, Технологический университет MARA (Малайзия, 78000, г. Малакка).

Дата поступления рукописи: 15.03.2020.

Прошла рецензирование: 29.06.2020. Принято решение о публикации: 18.12.2020.

Received: 15 Mar 2020

Reviewed: 29 Jun 2020

Accepted: 18 Dec 2020 